\title{
Double-Duty Actions to Reduce the Double Burden of Malnutrition in Indonesia
}

\author{
Rian Diana*1,2, Ikeu Tanziha ${ }^{3}$
}

\begin{abstract}
Background: Indonesia is facing a double burden of malnutrition (DBM). Double-duty action was promoted by WHO in 2017 which aims to tackle the double burden of malnutrition simultaneously.

Objectives: This study analyzed factors associated with the double burden of malnutrition and potential of double-duty action (DDA) that is suitable for Indonesia

Methods: This study is a provincial-level aggregate data set from Indonesia Basic Health Survey 2018 and National SocioEconomic Survey 2018 which covered 34 provinces. A serious DBM characterized by persistent stunting (children under five) $\geq 30 \%$ and coexisting overweight and obesity in adults $\geq 30 \%$ at the same time. Partial Least Squares Structural Equation Modeling (PLS-SEM) was used to analyze factors associated with DBM.

Results: High prevalence of stunting and overweight and obesity in almost all provinces di Indonesia. Seventeen provinces were having a serious DBM. Health care access, exclusive breastfeeding and socio-economic associated with DBM. There were 4 potential DDA for Indonesia: health care which consist of antenatal care, maternal and child care, exclusive breastfeeding, child growth monitoring, and social safety net. Conclusions: Addressing the DBM through four potential DDA can be a new paradigm, mindset, and critical importance in achieving Indonesia's target in reducing under and over nutrition simultaneously.
\end{abstract}

Keywords: double-duty action, overweight, obesity, double burden of malnutrition, stunting.

\author{
*Koresponden: \\ Rian Diana \\ Email : rian.diana@fkm.unair.ac.id \\ ${ }^{1}$ Departemen Gizi Kesehatan, Fakultas Kesehatan Masyarakat, Universitas Airlangga \\ ${ }^{2}$ Sekolah Pascasarjana, Institut Pertanian Bogor \\ ${ }^{3}$ Departemen Gizi Masyarakat, Fakultas Ekologi Manusia, Institut Pertanian Bogor
}

\section{INTRODUCTION}

Multiple nutritional problems (MGG) is a condition of the presence of malnutrition problems (stunting, wasting, and micronutrient deficiency) along with over nutrition and obesity throughout life ${ }^{1}$. Over nutrition and lifestyle problems associated with noncommunicable diseases such as diabetes mellitus, disease cardiovascular, hypertension, and cancer. Multiple nutrition problems can occur at the level of individuals, households and communities ${ }^{1}$. Almost all countries in the world experience MGG, both high and low income countries. The 2020 Global Nutrition Report shows that out of 143 countries in the world, as many as 124 countries $(86.7 \%)$ have at least two serious nutritional problems. Of the 124 countries, 37 countries have three serious nutritional problems (toddler stunting, anemia, and overweight in adult women) ${ }^{2}$.

The problem of multiple nutrition has become a concern in Indonesia although the main priority of the Indonesian government is still the problem of malnutrition, particularly stunting and malnutrition. Riskesdas 2007 and 2018 data shows that malnutrition problems for children under five (malnutrition, malnutrition, wasting, and stunting) in general have a downward trend in the last decade, but are still a serious public health problem in Indonesia. Meanwhile, SEZ among women of childbearing age, anemia in pregnant women, and obesity in adolescents and adults had an increasing trend compared to 10 years ago. Along with the increasing prevalence of obesity, the prevalence of diet-related non-communicable diseases (PTM) such as hypertension, diabetes mellitus, cancer and stroke also has an increasing trend ${ }^{3}$.

MGG can cause problems throughout the life cycle. Malnutrition in early life is the leading cause of one third of child deaths. One fifth of the burden of disease is caused by malnutrition in children and mothers ${ }^{1}$. Stunting experienced by children in early life can result in less optimal cognitive development and productivity as adults. If malnutrition occurs in women as teenagers or pregnant, it can cause pregnancy complications and nutritional problems between generations. If malnutrition as a child is accompanied by weight gain in the next phase of life, it can increase the risk of obesity and diet-related PTM ${ }^{1,4,5}$.

MGG is related to changes that occur in the world such as nutrition transition problems, demographic transitions, and epidemiological transitions. The causes of nutrition transition problems (from malnutrition to 
overnutrition) can be grouped into 4 major themes, namely (a) Biological / health environment; (b) food / economic environment; (c) physical environment; and (d) social / cultural environment ${ }^{6}$.

On April 1, 2016, the General Assembly of the United Nations (UN) issued a resolution of the United Nations Decade of Action on Nutrition from 2016 to 2025 which is in accordance with the framework of the Sustainable Development Goals (SDGs) 2030 7. This decade's nutrition action aims to increase action to end hunger, and eliminating all forms of under and over nutrition in the world and ensuring access to a healthy and sustainable diet universally for all people, regardless of who and where they live ${ }^{8}$. Through this resolution, the United Nations invites and encourages all parties including governments, organizations national and international, the private sector, academia, and society to contribute to achieving the SDGs goals in solving nutritional problems in all forms including the problem of multiple nutrition.

In 2017, WHO initiated Double-Duty Actions (DDA), an integrated effort to solve the problem of multiple nutrition. This DDA includes interventions, policies and programs that simultaneously have the potential to reduce the risk of underweight nutrition (wasting, stunting, and micronutrient deficiency) and overnutrition (overweight, obesity and PTM related to diet. There are 4 sectors that need attention. in completing MGG, namely health services, social safety networks, education, and food systems and the food environment ${ }^{9}$. Of the four sectors there are 5 candidates submitted by WHO, namely 6 months of exclusive breastfeeding, nutrition and health care programs for pregnant women, complementary feeding Proper breastfeeding, trade rules and marketing of formula milk and food that have implications for obesity and PTM, as well as school food policies and programs ${ }^{10}$. The five candidates then developed into 10 candidates, namely health services for pregnant women, exclusive breastfeeding, feeding babies and children, monitoring child growth, use of supplements and fortific foods social safety nets, school feeding programs, agriculture sensitive nutrition programs, food system policies that support a healthy diet and promote a healthy eating environment ${ }^{9}$.

The DDA introduced by WHO is a global recommendation. WHO states that DDA does not need a new program. However, it can be seen from the existing programs that have the potential to solve multiple nutritional problems simultaneously ${ }^{10}$. Efforts to prevent and control MGG through increasing the effectiveness of specific and sensitive nutrition interventions, based on data, and according to local conditions, are starting to get the attention of the Indonesian government. Therefore, to find out the potential of DDA in accordance with the conditions in Indonesia, this article will analyze the factors associated with multiple nutritional problems in Indonesia.

\section{METHOD}

Data
This study analyzes aggregate data from 34 provinces in Indonesia. Data were obtained from the 2018 Basic Health Research (Riskesdas) and the 2018 National Socio-Economic Survey (Susenas). Basic health research (Riskesdas) is a national scale survey with a cross sectional design conducted by the Health Research and Development Agency (Balitbangkes) of the Ministry of Health. Anthropometric measurements were carried out using a digital weight scale (accuracy level of $0.1 \mathrm{~kg}$ ), stadiometer height / length measuring instrument (accuracy level of $1 \mathrm{~cm}$ ), and measuring instrument for upper arm circumference using a measuring tape (accuracy level of $1 \mathrm{~cm})^{3}$.

The National Socio-Economic Survey (Susenas) is a national survey conducted annually by BPS. Susenas has 3 modules, namely the household consumption / expenditure module, the social, cultural and educational module, and the housing and health module. The data analyzed in this article are socio-economic and consumption 11. The household consumption / expenditure module from Susenas is then analyzed by BKP to produce data on the diversity of food consumption or the provincial score of expected food patterns (PPH) ${ }^{12}$.

\section{Measurement}

The dependent variable in this study is a multiple nutritional problem at the population level. An area has serious multiple nutritional problems if it has malnutrition problems in children under five, namely stunting ( $Z$ score TB / $U<-2$ SD) $\geq 30 \%$ along with obesity problems in adults aged $>18$ years (BMI $\geq 25 \mathrm{~kg} / \mathrm{m} 2$ ) by $30 \%{ }^{13}$. The independent variables are access and health services, exclusive breastfeeding, the pattern of care for feeding infants and children (PMBA), food environment, and socio-economic conditions. Indicators of access and health services include easy access to health facilities, antenatal care, 4 visits to health services (ANC K4), the proportion of pregnant women taking blood plus tablets $\geq 90$ tablets, ownership of the Maternal and Child Health (KIA) book, complete basic immunization in children aged 12-23 months, as well as access to proper sanitation and water sources.

Parenting patterns and feeding behavior for infants and children (PMBA) include indicators of early initiation of breastfeeding (IMD), provision of prelacteal feeding to infants, provision of colostrum, various foods, and the proportion of underwritten children who are still breastfed using the Riskesdas 2018 questionnaire ${ }^{3}$. IMD is determined by asking whether immediately after the baby is born, it is placed on the mother's chest / stomach with the mother's skin attached to the baby's skin, when does it begin to be placed on the mother's chest / stomach after thawing and how long does the process take ( $<1$ hour or $\geq 1$ hour). The mother performs an IMD if the baby (0-23 months) has a history of being placed on the mother's chest / stomach immediately after birth (1 hour after birth). Prelacteal food is asked by asking about the food / drink that has been given to the baby before breastfeeding or before the milk comes out. Children aged 6-23 years have a more diverse diet if they consume more than 4 of the 7 food groups consumed 24 hours previously. The seven food groups are (1) cereals and 
tubers; (2) nuts; (3) milk and its processed products (yogurt, milk, cheese, etc.); (4) meat (fish, chicken, beef, liver, etc.); (5) eggs; (6) vegetables and fruit sources of vitamin $A$; (7) other vegetables and fruits ${ }^{3}$.

Food environmental variables include indicators of food consumption diversity as seen from PPH scores, consumption of sweet drinks, salty foods, and fatty / fried foods for people aged $\geq 3$ years. Socio-economic variables include indicators of poverty levels, dependency ratios, and the percentage of the population with high food insecurity. The poverty level is seen from the percentage of poor people (below the poverty line). The dependency ratio is the ratio between the total population of the nonlabor force (aged 0-14 years plus the age of population above 65 years) and the total population of the workforce (15-64 years). Food insecurity is seen from the population who have a minimum calorie intake below $1400 \mathrm{kcal} /$ capita / day

\section{Statistical analysis}

The relationship between MGG and access to health services, exclusive breastfeeding, PMBA, food environment, and socioeconomic analysis was analyzed by using Partial Least Squares Structural Equation Modeling (PLS-SEM) with a confidence level of $95 \%(\alpha=$ $0.05 ; \mathrm{t}=1.96$ ). Data analysis using SmartPLS 2.0 software (SmartPLS GmbH, Hamburg, Germany). The validity and reliability of the variables were seen from the loading factor, composite reliability and Cronbach Alpha value. Loading factor $>0.7$ indicates the indicators used are valid for measuring constructs (variables). The value of composite reliability and Cronbach Alpha> 0.7 indicates that the construct (variable) has a good reliability value.

\section{RESULT AND DISCUSSION}

\section{Nutritional Problem in Indonesia}

Stunting and obesity have become public health problems in Indonesia in 2018 (stunting 30.8\%; overweight $35.4 \%$ ). Almost all provinces in Indonesia have stunting and obesity problems. The prevalence of stunting ranged from $17.6 \%$ to $42.7 \%$. Meanwhile, the prevalence of obesity is between $19.1 \%$ and $46.5 \%$. East Nusa Tenggara and West Sulawesi are the two provinces with the highest stunting prevalence $(>40 \%)$ and DKI Jakarta is the only province that has a stunting prevalence below $20 \%$. On the other hand, there are 5 provinces with a very high prevalence of adult obesity ( $>40 \%$ ), namely North Sulawesi, DKI Jakarta, East Kalimantan, North Sumatra, and North Kalimantan. Only East Nusa Tenggara has an obesity prevalence of less than $20 \%$ (Table 1).

Based on the criteria for multiple nutritional problems (30\% stunting under five and $30 \%$ overweight), Indonesia is currently experiencing serious MGG (stunting $30.8 \%$; overweight $35.4 \%$ ). The distribution of these serious MGGs is fairly even from the western to eastern parts of Indonesia. Of the 34 provinces in Indonesia, 17 provinces $(50 \%)$ experience serious double nutrition problems, 14 (41.2\%) provinces experience obesity problems, and 2 provinces experience stunting problems (West Nusa Tenggara and East Nusa Tenggara). Lampung
Province is the only province that does not have serious MGG (Table 1). The problem of obesity began to dominate compared to the problem of stunting. This transition in nutrition is in line with the global trend in nutrition, namely the problem of malnutrition is decreasing while the problem of malnutrition is increasing. 14. One of the determinants of this nutritional transition is diet change. An unhealthy diet can increase the risk of illness and death from PTM ${ }^{15}$.

\section{Factors Associated with Multiple Nutrient Deficiency}

The results of this study indicate that access to health services, exclusive breastfeeding, and socioeconomic conditions are factors that are associated with MGG in Indonesia. Meanwhile, PMBA and the food environment did not have a significant relationship with MGG. In general, health access and services in Indonesia are not yet optimal, especially in areas experiencing MGG (Table 2). All indicators of access and health services in MGG areas have lower coverage and proportions compared to regions without MGG. Easy access to health facilities in Indonesia is still very low (35.4\%). Likewise with the ANC K4 visit of pregnant women (67.3\%), consumption of blood-supplemented tablets for pregnant women $\geq 90$ tablets (32\%), ownership of $\mathrm{MCH}$ books (63.5\%), and complete immunizations for children 12-23 months $(56,2 \%)$. Table 3 shows that all indicators such as easy access to health facilities, ANC K4 visits, possession of $\mathrm{MCH}$ books, complete immunization for children 12-23 months, access to proper water and sanitation sources, and consumption of blood-supplemented tablets for pregnant women $\geq 90$ tablets can describe access and good health services (factor loading $>0.5$ ).

The results of this study indicate that access to health and health services is associated with exclusive breastfeeding ( $\beta=0.536, \mathrm{t}$ value $=4.096)$, PMBA $(\beta=$ $0.481, \mathrm{t}$ value $=5.752$ ) and MGG. Access to good health and health services can reduce MGG $(\beta=-0.457$, $\mathrm{t}$ value $=$ 2.712 ). On the other hand, low socioeconomic conditions can reduce access to health services $(\beta=-0.697$, $\mathrm{t}$ value $=$ 14.489) (Table 4).

Exclusive breastfeeding coverage for 6 months in Indonesia has only reached $45.4 \%$. Exclusive breastfeeding coverage was most widespread in the MGG area and without MGG (Table 2). Table 4 shows that exclusive breastfeeding has a positive relationship with MGG problems $(\beta=0.279$, $\mathrm{t}$ value $=2.140$ ). Exclusive breastfeeding is related to the practice of PMBA $(\beta=$ $0.359, \mathrm{t}$ value $=3.121$ )

The practice of PMBA in Indonesia is generally less than optimal. More than half $(54.8 \%)$ of mothers in Indonesia undertake IMD. The provision of colostrum $(83.5 \%)$ and breast milk until the child was two years old (76.5\%) had a fairly good proportion above $70 \%$. However, prelacteal feeding in infants is still quite high $(32.7 \%)$ and the consumption of a variety of foods for children under two years is still low (39.9\%). PMBA practice is slightly better in areas without MGG than in areas experiencing MGG (Table 2 ). 
Table 1. Provincial distribution based on nutrition problems

\begin{tabular}{|c|c|c|c|}
\hline No & Province & Toddler Stunting(\%) & Adult Overweight(\%) \\
\hline \multicolumn{4}{|c|}{ Areas that do not experience multiple nutritional problems } \\
\hline 1 & Lampung & 27,3 & 29,6 \\
\hline \multicolumn{4}{|c|}{ Areas with stunting problems } \\
\hline 1 & Nusa Tenggara Barat & 33,5 & 26,7 \\
\hline 2 & Nusa Tenggara Timur & 42,7 & 19,1 \\
\hline \multicolumn{4}{|c|}{ Areas that experience obesity problems } \\
\hline 1 & Sumatera Barat & 29,9 & 33,5 \\
\hline 2 & Riau & 27,4 & 38,1 \\
\hline 3 & Bengkulu & 28 & 33,1 \\
\hline 4 & Bangka Belitung & 23,4 & 37,4 \\
\hline 5 & Kepulauan Riau & 23,6 & 39,8 \\
\hline 6 & DKI Jakarta & 17,6 & 45,4 \\
\hline 7 & DI Yogyakarta & 21,3 & 34,7 \\
\hline 8 & Banten & 26,6 & 35,3 \\
\hline 9 & Bali & 21,9 & 38,8 \\
\hline 10 & Kalimantan Timur & 29,2 & 44,2 \\
\hline 11 & Kalimantan Utara & 26,9 & 40,3 \\
\hline 12 & Sulawesi Utara & 25,5 & 46,5 \\
\hline 13 & Sulawesi Tenggara & 28,7 & 32,4 \\
\hline 14 & Papua Barat & 27,8 & 39,7 \\
\hline \multicolumn{4}{|c|}{ Daerah yang mengalami masalah gizi ganda } \\
\hline 1 & Aceh & 37,1 & 38,3 \\
\hline 2 & Sumatera Utara & 32,4 & 40,6 \\
\hline 3 & Jambi & 30,2 & 30,9 \\
\hline 4 & Sumatera Selatan & 31,6 & 30,3 \\
\hline 5 & Jawa Barat & 31,1 & 36,7 \\
\hline 6 & Jawa Tengah & 31,3 & 33,4 \\
\hline 7 & Jawa Timur & 32,8 & 36,1 \\
\hline 8 & Kalimantan Barat & 33,3 & 30,2 \\
\hline 9 & Kalimantan Tengah & 34,0 & 31,9 \\
\hline 10 & Kalimantan Selatan & 33,1 & 32,9 \\
\hline 11 & Sulawesi Tengah & 32,3 & 34,5 \\
\hline 12 & Sulawesi Selatan & 35,7 & 32,1 \\
\hline 13 & Gorontalo & 32,5 & 39,3 \\
\hline 14 & Sulawesi Barat & 41,6 & 31,4 \\
\hline 15 & Maluku & 34,0 & 32,8 \\
\hline 16 & Maluku Utara & 31,4 & 38,0 \\
\hline 17 & Papua & 33,1 & 35,1 \\
\hline Indonesia & & 30,8 & 35,4 \\
\hline
\end{tabular}

Sumber: Riskesdas (2018)

Table 3 shows that a good PMBA can be illustrated by indicators of a high proportion of $\mathrm{BMI}$, colostrum, breast milk until children aged two years, and a variety of food consumption for children under five years of age, and low prelacteal feeding of infants. This shows that the indicators used are valid to describe PMBA. The results of the PLS-SEM further analysis in Table 4 show that there is no significant relationship between PMBA and MGG $(\beta=0.348, t$ value $=1.497)$.

In the food environment aspect, the diversity of consumption of the Indonesian population still needs to be improved (PPH score 86.8). Areas without MGG have a slightly better food environment than areas with MGG. The diversity of food consumption (PPH score) in areas without MGG is higher than that in areas with MGG. On the other hand, the consumption of sweet drinks, salty foods, and fatty / fried foods is more consumed by residents of MGG areas than in areas without MGG (Table 2).

Consumption of sugary drinks, salty foods, and fatty / fried foods of people aged $\geq 3$ years significantly reflects a poor food environment (Table 3). However, the results of PLS-SEM analysis showed no significant relationship between the food environment and MGG ( $\beta$ $=-0.257, \mathrm{t}$ value $=0.287$ ) (Table 4).

Table 2 shows that the poverty rate $(10.6 \%)$, the proportion of the population is very food insecure $(10.5 \%)$, and the dependency ratio (50.6) in Indonesia is quite high. Regions without MGG have lower levels of poverty, dependency ratios, and the proportion of people with high food insecurity than areas with MGG. The poverty rate, the proportion of the population highly 
insecure to food and the high dependency ratio illustrates low socio-economic conditions (Table 3 ). The results of the PLS-SEM analysis show that socio-economic conditions are related to the food environment $(\beta=$ -
$0.461, \mathrm{t}$ value $=2.654)$, access to health services $(\beta=-$ $0.697, \mathrm{t}$ value $=14.489)$, exclusive breastfeeding $(\beta=$ $0.537, \mathrm{t}$ value $=5.338)$, and MGG $(\beta=0.361, \mathrm{t}$ value $=$ 2.263).

Table 2. Mean and standard deviation of indicators of multiple nutritional problems

\begin{tabular}{|c|c|c|c|}
\hline Variabel & MGG & Tidak MGG & Total \\
\hline \multicolumn{4}{|l|}{ Health access and services } \\
\hline Easy access to health facilities (\%) & $30,6 \pm 6,5$ & $40,1 \pm 13,6$ & $35,4 \pm 11,6$ \\
\hline ANC K4 Visits (\%) & $63,4 \pm 11,3$ & $71,2 \pm 11,1$ & $67,3 \pm 11,7$ \\
\hline Ownership of KIA books(\%) & $61,4 \pm 13,6$ & $65,7 \pm 9,7$ & $63,5 \pm 11,8$ \\
\hline $\begin{array}{l}\text { Complete immunization of children } 12- \\
23 \text { months (\%) }\end{array}$ & $50 \pm 15,7$ & $62,3 \pm 16,2$ & $56,2 \pm 16,9$ \\
\hline Access to improved water sources (\%) & $70,0 \pm 6,1$ & $75,9 \pm 11,0$ & $72,9 \pm 9,3$ \\
\hline Access to proper sanitation (\%) & $64,2 \pm 10,3$ & $72,5 \pm 14,3$ & $68,4 \pm 12,9$ \\
\hline $\begin{array}{l}\text { Consumption of blood-suplemented } \\
\text { tablets for pregnant women } \geq 90 \\
\text { tablets (\%) }\end{array}$ & $28,1 \pm 10,1$ & $35,8 \pm 15,9$ & $32 \pm 13,7$ \\
\hline $\begin{array}{l}\text { Children under five don't get vitamin A } \\
\text { (\%) }\end{array}$ & $20,8 \pm 6,9$ & $17,5 \pm 4,7$ & $19,2 \pm 6,1$ \\
\hline \multicolumn{4}{|l|}{ Exclusive breastfeeding } \\
\hline Exclusive breastfeeding (\%) & $45,6 \pm 10,2$ & $45,1 \pm 11,2$ & $45,4 \pm 10,5$ \\
\hline \multicolumn{4}{|l|}{ PMBA } \\
\hline $\begin{array}{l}\text { Early initiation of breastfeeding (IMD) } \\
\text { (\%) }\end{array}$ & $53,2 \pm 9,5$ & $56,4 \pm 10,2$ & $54,8 \pm 9,8$ \\
\hline Prelacteal feeding of infants (\%) & $33,9 \pm 10$ & $31,6 \pm 9,1$ & $32,7 \pm 9,4$ \\
\hline Colostrum administration (\%) & $81,0 \pm 6,6$ & $86,1 \pm 6,2$ & $83,5 \pm 6,8$ \\
\hline Breastfed Baduta children (\%) & $76,9 \pm 6,2$ & $76,2 \pm 5,9$ & $76,5 \pm 6$ \\
\hline $\begin{array}{l}\text { Food consumption of various baduta } \\
(\%)\end{array}$ & $36,7 \pm 10,9$ & $43,1 \pm 12,4$ & $39,9 \pm 11,9$ \\
\hline \multicolumn{4}{|l|}{ Food environment } \\
\hline Average AKE (\%) & $104 \pm 6,2$ & $106,8 \pm 5,8$ & $107,9 \pm 9,5$ \\
\hline Average PPA (\%) & $113,3 \pm 10,2$ & $120,6 \pm 9,9$ & $120,7 \pm 9,5$ \\
\hline PPH Score & $82,2 \pm 7,4$ & $85,7 \pm 5,5$ & $86,8 \pm 5,1$ \\
\hline Consumption of sweet foods (\%) & $41,8 \pm 6,5$ & $38,3 \pm 5,2$ & $40,1 \pm 6$ \\
\hline Consumption of sweetened drinks (\%) & $60,3 \pm 4,8$ & $59,2 \pm 6,6$ & $59,7 \pm 5,7$ \\
\hline Consumption of salty foods (\%) & $23,3 \pm 11,2$ & $18,5 \pm 8,3$ & $20,9 \pm 10$ \\
\hline Consumption of fatty / fried foods (\%) & $33 \pm 11,5$ & $32,5 \pm 10,3$ & $32,7 \pm 10,8$ \\
\hline $\begin{array}{l}\text { Consume } 5 \text { servings of fruits and } \\
\text { vegetables a day (\%) }\end{array}$ & $4,8 \pm 2$ & $5,9 \pm 2,3$ & $5,3 \pm 2,2$ \\
\hline \multicolumn{4}{|l|}{ Social economy } \\
\hline Poverty level (\%) & $11,4 \pm 5,6$ & $9,9 \pm 5,8$ & $10,6 \pm 5,7$ \\
\hline $\begin{array}{l}\text { The population is very food insecure } \\
(\%)\end{array}$ & $12 \pm 7,2$ & $9 \pm 4,9$ & $10,5 \pm 6,2$ \\
\hline Dependency ratio & $51 \pm 4,5$ & $50,1 \pm 6,6$ & $50,6 \pm 5,5$ \\
\hline
\end{tabular}

Sumber: Riskesdas (2018); Susenas (2018)

The model structure of the relationship between access and health services, exclusive breastfeeding, PMBA, food environment and socioeconomic conditions can be seen in Figure 1. This model is quite valid and reliable seen from the loading factor value, Cronbach alpha, composite reliability and average variance extracted, almost all of which meet the specified threshold criteria, namely $0.7,0.7,0.7$, and 0.5 respectively (Table 3 ). The value of $\mathrm{R} 2$ obtained from the model structure of the factors related to MGG is $50.8 \%$. This moderate $\mathrm{R} 2$ value is still acceptable because the Goodness of Fit value is high, namely 0.476 .

The potential of DDA in Indonesia
Based on the explanation above, access and health services, exclusive breastfeeding, and socioeconomic conditions have the potential to become DDA in Indonesia. There are 2 factors that are considered in the selection of potential DDA and in accordance with the conditions, namely; (1) the policies or programs implemented do not increase the risk of malnutrition in other forms or increase the risk of PTM, (2) The choice of DDA is made from existing policies or programs, and whether this has the potential to prevent other malnutrition 10. Based on the DDA proposal From WHO, the programs running in Indonesia, and the factors related to MGG that have been presented in this article, there are two major components that have the potential 
to become DDA in Indonesia. The two major components are health services and social safety networks which consist of 4 potential DDA (nutrition and health services for pregnant women and children, monitoring of child growth, exclusive breastfeeding, and social safety networks).

Table 3. Validity and reliability of variables and indicators of multiple nutritional problems

\begin{tabular}{|c|c|c|c|c|c|}
\hline Variabel & $\begin{array}{l}\text { Factor } \\
\text { Loading }\end{array}$ & t value & $\begin{array}{l}\text { Cronbach } \\
\text { Alpha }\end{array}$ & $\begin{array}{l}\text { Composite } \\
\text { Reliability }\end{array}$ & $\begin{array}{l}\text { Average } \\
\text { Varian } \\
\text { Extracted }\end{array}$ \\
\hline Health access and services & & & 0,863 & 0,895 & 0,556 \\
\hline Easy access to health facilities (\%) & 0,841 & 17,156 & & & \\
\hline ANC K4 Visits (\%) & 0,864 & 23,754 & & & \\
\hline Ownership of KIA books(\%) & 0,621 & 7,021 & & & \\
\hline $\begin{array}{l}\text { Complete immunization of children } \\
12-23 \text { months (\%) }\end{array}$ & 0,846 & 28,787 & & & \\
\hline $\begin{array}{l}\text { Access to improved water sources } \\
(\%)\end{array}$ & 0,534 & 5,003 & & & \\
\hline Access to proper sanitation (\%) & 0,692 & 7,918 & & & \\
\hline $\begin{array}{l}\text { Consumption of blood-suplemented } \\
\text { tablets for pregnant women } \geq 90 \\
\text { tablets (\%) }\end{array}$ & 0,772 & 9,758 & & & \\
\hline $\begin{array}{l}\text { Children under five don't get vitamin } \\
\mathrm{A}(\%)\end{array}$ & & & 1,000 & 1,000 & 1,000 \\
\hline Exclusive breastfeeding & 1,000 & 0,000 & & & \\
\hline Exclusive breastfeeding (\%) & & & 0,399 & 0,702 & 0,529 \\
\hline PMBA & 0,854 & 8,576 & & & \\
\hline $\begin{array}{l}\text { Early initiation of breastfeeding } \\
\text { (IMD) (\%) }\end{array}$ & $-0,593$ & 3,466 & & & \\
\hline Prelacteal feeding of infants (\%) & 0,856 & 9,035 & & & \\
\hline Colostrum administration (\%) & 0,437 & 2,997 & & & \\
\hline Breastfed Baduta children (\%) & 0,800 & 7,467 & & & \\
\hline $\begin{array}{l}\text { Food consumption of various baduta } \\
\text { (\%) }\end{array}$ & & & 0,589 & 0,775 & 0,501 \\
\hline Food environment & 0,215 & 1,039 & & & \\
\hline Average AKE (\%) & 0,697 & 6,526 & & & \\
\hline Average PPA (\%) & 0,799 & 11,924 & & & \\
\hline PPH Score & 0,913 & 25,870 & & & \\
\hline Consumption of sweet foods (\%) & & & 0,653 & 0,810 & 0,586 \\
\hline $\begin{array}{l}\text { Consumption of sweetened drinks } \\
\text { (\%) }\end{array}$ & 0,761 & 12,368 & & & \\
\hline Consumption of salty foods (\%) & 0,744 & 10,670 & & & \\
\hline $\begin{array}{l}\text { Consumption of fatty / fried foods } \\
\text { (\%) }\end{array}$ & 0,792 & 10,195 & & & \\
\hline
\end{tabular}

\section{Health services}

A strong primary health service can improve the public health status. This health service includes health and care for pregnant women, breastfeeding mothers, babies, children, prevention of PTM, and increasing access to easy health facilities. Easy access to health facilities, visits of pregnant women to health services at least 4 times, possession of MCH books, complete child immunizations, consumption of $\geq 90$ tablets of blood plus tablets for pregnant women, and access to clean water and proper sanitation related to MGG in Indonesia. Therefore, strong primary health services, as well as access to clean water and proper environmental sanitation are the potential of DDA in completing MGG in Indonesia.

Health facilities that can be accessed easily in terms of location, cost and travel time, especially for the poor and vulnerable groups will have a positive impact on reducing MGG. PLS-SEM analysis shows that good health access and services can increase exclusive breastfeeding and good IYCF practice. The results of this study corroborate the results of previous studies which state that easy access to health facilities can affect the nutrition and health of mothers and children ${ }^{16-18}$. Regions without MGG have health facilities that are more accessible than MGG areas. Ease of access to health facilities can be achieved by the availability of health facilities in each village, be it a midwife / auxiliary puskesmas / clinic / other health facilities. The PLS-SEM analysis results show that socio-economic conditions are related to access to health facilities. The lower the socioeconomic level of a region (poverty level, the proportion of the population is very food insecure, and the high dependency ratio), the lower the access to health services. 


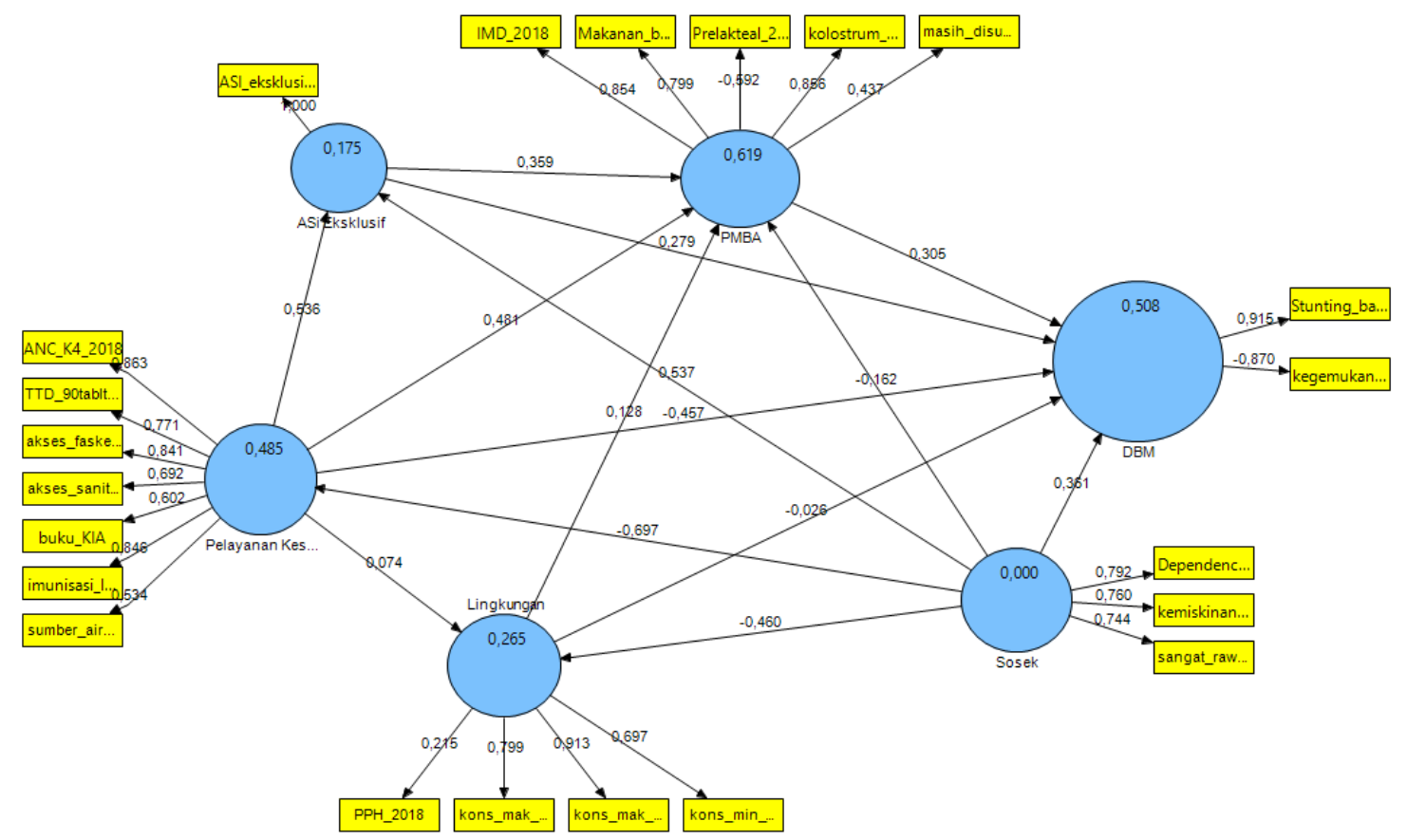

Figure 1. Factors associated with multiple nutritional problems

Increasing economic access to access to health services can be improved by increasing health insurance coverage. The existence of health protection guarantees affects the nutrition and health of the child's mother ${ }^{19,20}$.

Maternal and toddler health services. Services related to nutrition and maternal health can focus on improving the nutrition and health of pregnant women through regular ANC visits at least 4 times during pregnancy, consumption of blood plus tablets for pregnant women $\geq 90$ tablets, complete immunization for under-five, and all pregnant women must have a KIA book. The $\mathrm{MCH}$ Handbook is a media for monitoring development and education on nutrition and health for mothers and children. This $\mathrm{MCH}$ book contains nutrition and health education for mothers and children, development of pregnant women, child growth and development, as well as education on feeding for mothers and children. The results of the 2013 Riskesdas analysis by Titaley et al showed that pregnant women who had pregnancy checks less than 4 times had a higher chance of having a child who was stunted ${ }^{21}$.

Table 4. Path coeffecient model

\begin{tabular}{lccl}
\hline & $\boldsymbol{B}$ & $\boldsymbol{t}$ value & \multicolumn{1}{c}{ Result } \\
\hline Access and Health Services -> DBM & $-0,457$ & 2,712 & Significant \\
Exclusive breastfeeding -> DBM & 0,279 & 2,140 & Significant \\
PMBA -> DBM & 0,348 & 1,497 & Not significant \\
Food environment -> DBM & $-0,257$ & 0,287 & Not significant \\
Social - D DBM & 0,361 & 2,263 & Significant \\
Access and Health Services -> PMBA & 0,481 & 5,752 & Significant \\
Exclusive breastfeeding -> PMBA & 0,359 & 3,121 & Significant \\
Food environment -> PMBA & 0,128 & 1,246 & Not significant \\
Social -> PMBA & $-0,162$ & 1,660 & Not significant \\
Access and Health Services -> Exclusive breastfeeding & 0,536 & 4,096 & Significant \\
Social -> Exclusive breastfeeding & 0,537 & 5,338 & Significant \\
Access and Health Services -> Food environment & 0,742 & 0,468 & Not significant \\
Social -> Food environment & $-0,461$ & 2,654 & Significant \\
Sosek -> Health Service and Access & $-0,697$ & 14,489 & Significant \\
\hline
\end{tabular}

Good environmental sanitation and high access to clean water can reduce the incidence of infectious disease transmission and improve environmental hygiene. The results of the study by Torlesse et al show that access to clean water, sanitation and hygiene need to be considered in reducing stunting in Indonesia ${ }^{22}$.
Promotion and support for exclusive breastfeeding for 6 months needs to be expanded because of the low coverage of exclusive breastfeeding in Indonesia $(<50 \%)$. The potential for exclusive breastfeeding in completing MGG is quite large. Several studies have shown that breastfeeding reduces the risk of obesity ${ }^{23-25}$ and stunting ${ }^{26}$. 
Monitoring of child growth needs to be carried out as an early detection of both deficiency and excess nutrition. Posyandu as an extension of maternal and child health services in Indonesia has an important role in

\section{Social Security}

Poverty is a risk factor for all types of malnutrition and vice versa malnutrition can also lead to poverty ${ }^{29.30}$.

of the population is very food insecure and the high dependency ratio is greater in MGG areas.

In areas with a poverty level, the population is very food insecure, and a high dependency ratio, nutrition and health vulnerable groups need to receive social security insurance (family hope program, non-cash food assistance, BPJS contribution assistance recipients) which is integrated with health services. In areas with high stunting problems, programs to improve access to water and proper sanitation need to be implemented ${ }^{22}$.

\section{CONCLUSION}

Indonesia is currently experiencing a serious dual nutrition problem. Of the 34 provinces, half have a serious double nutritional burden. Health access and services, exclusive breastfeeding, and socio-economic conditions are linked to multiple nutritional problems in Indonesia. Handling MGG in Indonesia requires basic action, namely addressing the problem of poverty and providing comprehensive health coverage for all citizens (universal health coverage). The reduction and prevention of MGG can focus on 4 potential DDA, namely nutrition and health services for pregnant women and children, monitoring child growth, exclusive breastfeeding, and social safety networks.

All of these policies and programs have been implemented by the Indonesian government, but are still in the context of addressing individual nutrition problems (stunting or obesity alone). The focus on 4 programs that have the potential to become DDA needs to be improved and expanded so that this program can complete MGG. This new paradigm and thinking can be a comprehensive approach to reduce the problem of under and over nutrition simultaneously.

\section{REFERENCE}

1. WHO Regional Office for South-East Asia. Strategic Action Plan to reduce the double burden of malnutrition in the South-East Asia Region 2016-2025. (WHO Regional Office for South-East Asia, 2016)

2. Development Initiatives. 2020 Global Nutrition Report: Action on equity to end malnutrition. (2020).

3. Badan Penelitian dan Pengembangan Kesehatan. Laporan Hasil Riset Kesehatan Dasar (Riskesdas) Indonesia tahun 2018. Riset Kesehatan Dasar 2018 182-183 (2019).

4. Wells, J. C. et al. The double burden of malnutrition: aetiological pathways and consequences for health. Lancet 395, P75-88 (2020).

5. Shrimpton, R. \& Rokx, C. The Double Burden of monitoring child growth ${ }^{27,28}$. Routine measurement of body weight and height every month at the posyandu is recorded on the health card (KMS) contained in the KIA book.

This can be seen from Table 1 which shows that poverty, the proportion

Malnutrition in Indonesia. (World Bank Jakarta, 2013).

6. Shrimpton, R. \& Rokx, C. HNP Discussion Paper Series. The Double Burden of Malnutrition: A Review of Global Evidence. (The World bank, 2012).

7. United Nations. United Nations Decade of Action on Nutrition (2016-2025). In: Seventieth session of United Nations General Assembly. Agenda Item 15. (2016). Available at: https://www.un.org/ga/search/view_doc.asp?s ymbol=A/70/L.42. (Accessed: 19th May 2020)

8. WHO. The double burden of malnutrition. Policy Brief. (2017).

9. Hawkes, C., Ruel, M. T., Salm, L., Sinclair, B. \& Branca, F. Double-duty actions : seizing programme and policy opportunities to address malnutrition in all its forms. Lancet 395, P142155 (2020).

10. WHO. Double-duty actions. Policy Brief. (2017).

11. BPS. Publikasi Statistik. (2020). Available at: https://www.bps.go.id/. (Accessed: 10th May 2020)

12. Badan Ketahanan Pangan. Statistik ketahanan pangan 2014-2018. (Badan Ketahanan Pangan, Kementerian Pertanian, 2019).

13. Popkin, B. M., Corvalan, C. \& Grummer-strawn, L. M. Dynamics of the double burden of malnutrition and the changing nutrition reality. Lancet 395, P65-74 (2020).

14. NCD Risk Factor Collaboration (NCS-RisC). Worldwide trends in body-mass index, underweight, overweight, and obesity from 1975 to 2016: a pooled analysis of 2416 population-based measurement studies in 128.9 million children, adolescents, and adults. Lancet 390, 2627-2642 (2017).

15. GBD 2017 Diet Collaborators. Health effects of dietary risks in 195 countries , 1990-2017 : a systematic analysis for the Global Burden of Disease Study. Lancet 393, 1958-72 (2019).

16. Nainggolan, O. Pengaruh Akses ke Fasilitas Kesehatan terhadap Kelengkapan Imunisasi Baduta ( Analisis Riskesdas 2013 ). Media Litbangkes 26, 15-28 (2016).

17. Jabbari-Beyrami, H. et al. Adequacy of prenatal care and its association with pregnancy outcomes: A comparison of indices in Tabriz, Iran. J Anal Res Clin Med 3, 12-16 (2015).

18. Sartika, R. A. D. Analisis Pemanfaatan Program Pelayanan Kesehatan Status Gizi Balita. J. Kesehat. Masy. Nas. 5, 76-83 (2010).

19. Aderibigbe, S., Wit, F., van Hensbroek, M., Osagbemi, G. \& Akande, T. The effect of health 
insurance on maternal and child health : A systematic review. J. Med. Trop. 20, 83-92 (2018).

20. Nuñez, P. A. et al. Impact of Universal Health Coverage on Child Growth and Nutrition in Argentina. Am J Public Heal. 106, 720-726 (2016).

21. Titaley, C. R., Ariawan, I., Hapsari, D., Muasyaroh, A. \& Dibley, M. J. Determinants of the Stunting of Children Under Two Years Old in Indonesia : A Multilevel Analysis of the 2013 Indonesia Basic Health Survey. Nutrients 11, 1106 (2019).

22. Torlesse, H., Cronin, A. A., Sebayang, S. K. \& Nandy, R. Determinants of stunting in Indonesian children : evidence from a crosssectional survey indicate a prominent role for the water, sanitation and hygiene sector in stunting reduction. BMC Public Health 16, 669 (2016).

23. Lee, J. W. et al. The Protective Effect of Exclusive Breastfeeding on Overweight / Obesity in Children with High Birth Weight. J. Korean Med. Sci. 34, e85 (2019).

24. Uwaezuoke, S. N., Eneh, C. I. \& Ndu, I. K. Relationship Between Exclusive Breastfeeding and Lower Risk of Childhood Obesity : A Narrative Review of Published Evidence. Clin. Med. Insights Pediatr. 11, 1-7 (2017).
25. Yan, J., Liu, L., Zhu, Y., Huang, G. \& Wang, P. P. The association between breastfeeding and childhood obesity : a meta-analysis. BMC Public Health 14, 1276 (2014).

26. Barir, B., Murti, B. \& Pamungkasari, E. P. The Associations between Exclusive Breastfeeding, Complementary Feeding, and the Risk of Stunting in Children Under Five Years of Age : A Path Analysis Evidence from Jombang East Java. J. Matern. Child Heal. 4, 486-498 (2019).

27. Destiadi, A., Susila, T. N. \& Sumarmi, S. Frekkuensi kunjungan posyandu dan riwayat kenaikan berat badan sebagai faktor risiko kejadian stunting pada anak usia 3-5 tahun. Media Gizi Indones. 10, 71-75 (2015).

28. Sahanggamu, P. D., Purnomosari, L., Dillon, D. \& Indonesia, U. Information exposure and growth monitoring favour child nutrition in rural Indonesia. Asia Pac. J. Clin. Nutr. 26, 313-316 (2017).

29. Tanumihardjo, S. A. et al. Poverty, Obesity, and Malnutrition: An International Perspective Recognizing the Paradox. J. Am. Diet. Assoc. 107, 1966-1972 (2007).

30. WHO. Malnutrition. (2020). Available at: https://www.who.int/news-room/factsheets/detail/malnutrition. (Accessed: 22nd June 2020) 